\title{
Chromium Speciation in Wastewater and Sewage by Solid-Phase Extraction Using a New Diphenylcarbazone-Incorporated Resin
}

\author{
Barbara Leśniewska • Anna Jeglikowska • \\ Beata Godlewska-Żylkiewicz
}

Received: 8 April 2016 / Accepted: 4 July 2016/Published online: 29 July 2016

(C) The Author(s) 2016. This article is published with open access at Springerlink.com

\begin{abstract}
A new procedure for the determination of chromium species in polluted environmental samples by flame atomic absorption spectrometry was developed in this work. A new material containing 1,5diphenylcarbazone included in a polymeric matrix was prepared and employed as a solid-phase extraction material for selective separation of $\mathrm{Cr}$ (III) ions under dynamic conditions. Chromium(III) ions were retained on this sorbent with high efficiency and repeatability $(95 \%, \mathrm{RSD}=1 \%)$ from solutions with $\mathrm{pH}$ 9.0. The quantitative recovery of analyte was obtained with $0.1 \mathrm{~mol} \mathrm{~L}^{-1}$ EDTA. The concentration of $\mathrm{Cr}(\mathrm{VI})$ ions was calculated from the difference between the concentration of total chromium and $\mathrm{Cr}$ (III) ions. The prepared sorbent exhibits good chemical and mechanical stability, sorption capacity and selectivity towards $\mathrm{Cr}$ (III) ions in the presence of $\mathrm{Cu}(\mathrm{II}), \mathrm{Ni}(\mathrm{II}), \mathrm{Mn}$ (II) and $\mathrm{Ca}(\mathrm{II})$ ions. The accuracy of the separation method was proved by analysis of reference material of wastewater RES 10.2. The developed procedure was applied for chromium speciation analysis in municipal sewage samples.
\end{abstract}

B. Leśniewska $(\bowtie) \cdot$ A. Jeglikowska •

B. Godlewska-Żyłkiewicz

Institute of Chemistry, University of Bialystok, K. Ciołkowskiego

$1 \mathrm{~K}, 15-245$ Bialystok, Poland

e-mail: blesniew@uwb.edu.pl
Keywords Chromium(III) - Separation · Functionalized resin $\cdot$ FAAS $\cdot 1,5$-Diphenylcarbazone $\cdot$ Environmental analysis

\section{Introduction}

Chromium is considered a priority pollutant by the US Environmental Protection Agency due to significant quantities of its production and frequent occurrence in water systems (EPA 2014). Total chromium emission in 2013 in the European Union (EU-28) was $336 \mathrm{Mg}$, while in Poland was $47 \mathrm{Mg}$ (EEA Technical report 2015). The wide use of chromium in steel and electroplating industry, leather tanning, production of alloys and pigments leads to the discharge of significant quantities of liquid or solid wastes containing chromium into the environment, which pollutes groundwater and surface water, soils and plants (Kotaś and Stasicka 2000; Metze et al. 2005; Hoet 2005). The concentrations of chromium in wastewaters (such as electroplating or leather tanning wastewaters) are usually in the range of 3-30 $\mathrm{mg} \mathrm{L}^{-1}$ for $\mathrm{Cr}(\mathrm{VI})$ and $5-100 \mathrm{mg} \mathrm{L}^{-1}$ for total chromium. In Poland, according to the Ordinance of the Minister of Environment (2014) concerning the conditions for spreading sewage into the water or soil, the maximal concentration of chromium in sewage cannot exceed 0.05 $0.5 \mathrm{mg} \mathrm{L}^{-1}$ of $\mathrm{Cr}(\mathrm{VI})$ and $0.5-1 \mathrm{mg} \mathrm{L}^{-1}$ of total chromium, depending on the type of industry.

Two most stable oxidation states of chromium, $\mathrm{Cr}(\mathrm{III})$ and $\mathrm{Cr}(\mathrm{VI})$, exhibit different biological activity 
and toxic effect on living organisms. $\mathrm{Cr}$ (III) is an essential element for the proper functioning of living organisms, while $\mathrm{Cr}(\mathrm{VI})$ has an adverse effect on living organisms. Owing to its high toxicity, this metal constitutes a serious risk for health, whereas chronic exposure to it, even at low concentrations, may produce mutagenesis and carcinogenesis (IARC 1990; Report on Carcinogens 2014). Compounds of $\mathrm{Cr}(\mathrm{III})$ and $\mathrm{Cr}$ (VI) differ also in mobility under environmental conditions. More mobile species of Cr(VI) can undergo redox transformation forming labile and more stable species of $\mathrm{Cr}(\mathrm{III})$, Hence, speciation analysis of chromium in various environmental compartments and in humans is essential.

In speciation analysis of chromium by the spectrophotometric method, complexes of chromium at different oxidation states have been exploited. Spectrophotometric detection requires the transformation of one of the chromium species, most often $\mathrm{Cr}(\mathrm{VI})$, into a colourful form, which is able to absorb visible (vis) radiation. The most popular methods are based on the formation of complexes of $\mathrm{Cr}(\mathrm{VI})$ with 1,5diphenylcarbazide (DPC) (Mulaudzi et al. 2002; Ma et al. 2014), sodium diphenylamine sulfonate (Yuan et al. 2008) and chromotropic acid (Themelis et al. 2006) showing absorption maxima at $\lambda_{\max }=540,550$ and $370 \mathrm{~nm}$, respectively. Limits of detection of the proposed methods were $23 \mathrm{\mu g} \mathrm{L}^{-1}$ (Mulaudzi et al. 2002; Ma et al. 2014), $22 \mu \mathrm{g} \mathrm{L}^{-1}$ (Yuan et al. 2008) and $1 \mu \mathrm{g} \mathrm{L}^{-1}$ (Themelis et al. 2006).

In the reaction of $\mathrm{Cr}(\mathrm{VI})$ with $\mathrm{DPC}$, the ligand is oxidized by chromate ions to 1,5-diphenylcarbazone (DPCO) leading to the formation of a soluble redviolet complex of $\mathrm{Cr}(\mathrm{III})-\mathrm{DPCO}$. Although literature review shows that this method is most often used for the selective determination of $\mathrm{Cr}(\mathrm{VI})$, it suffers from the presence of interfering compounds, particularly $\mathrm{Cu}(\mathrm{II})$, $\mathrm{Mo}(\mathrm{VI}), \mathrm{Fe}(\mathrm{III}), \mathrm{V}(\mathrm{V})$ and $\mathrm{Hg}(\mathrm{II})$, which can react with the complexing agent giving positive interferences. A large excess of DPC is essential, as compounds present in the sample may consume the reagent. On the other hand, humic compounds present in the sample, including species that absorb at $540 \mathrm{~nm}$ (e.g., released from soil), interfere with the correct determination of $\mathrm{Cr}(\mathrm{VI})$ (Pettine and Capri 2005). Moreover, the Cr(III)-DPCO complex is photo-labile leading to a fast decrease of analytical signal. It was observed during measurement of Cr(III)-DPCO in solution by a thermal lens spectrometry (TLS) (Madzgalj et al. 2008). Due to these reasons, direct application of this method to real sample analysis is frequently restricted because of the effect of sample matrix compositions and relatively low sensitivity.

In order to obtain reliable results of chromium speciation analysis, enrichment and separation techniques, such as coprecipitation (Soylak and Kizil 2013), liquid-liquid extraction (Pena et al. 2008; Unsal et al. 2014), solid-phase extraction (Leśniewska et al. 2012; Leśniewska et al. 2015; Tunceli and Turker 2002; Narin et al. 2002) or chromatography (Stanisławska et al. 2013; Barałkiewicz et al. 2013), coupled to species non-specific detection techniques, such as flame atomic absorption spectrometry (FAAS) (Table 1) or electrothermal atomic absorption spectrometry (ETAAS) or inductively coupled plasma mass spectrometry (ICPMS), have been proposed (Table 1). These methods have been extensively discussed in several review papers (Zhao et al. 2012; Pyrzyńska 2012; Namieśnik and Rabajczyk 2012; Ščančar and Milačič 2014). The solidphase extraction (SPE) separation methods used for chromium speciation are mostly based on the separation and determination of one of the chromium forms ( $\mathrm{Cr}$ (III) or $\mathrm{Cr}(\mathrm{VI})$ ). The content of the second form is determined after its oxidation/reduction or as a difference between total chromium and the initially determined form. Commercial or modified/functionalized materials such as chelating resins, anion or cation exchangers and adsorptive resins are typically used as solid sorbents.

The solid-phase extraction methods using the DPC agent for chromium speciation analysis are mostly based on the formation of the Cr(III)-diphenylcarbazone complex and its retention on adsorption resin such as Amberlite XAD-16 (Tunceli and Turker 2002), Amberlite XAD-4 (Rajesh et al. 2008), Amberlite XAD-1180 (Narin et al. 2008) or Ambersorb 563 (Narin et al. 2006). The content of $\mathrm{Cr}(\mathrm{VI})$ was determined after elution of the retained complex from the column by UV-vis spectrophotometry (Rajesh et al. 2008; Narin et al. 2006) or FAAS (Tunceli and Turker 2002; Narin et al. 2002; Narin et al. 2008). Total chromium was determined after conversion of $\mathrm{Cr}$ (III) to $\mathrm{Cr}(\mathrm{VI})$ by oxidation with $\mathrm{KMnO}_{4}$ (Tunceli and Turker 2002) or $\mathrm{K}_{2} \mathrm{~S}_{2} \mathrm{O}_{8}$ in an acidic medium (Narin et al. 2006; Narin et al. 2008). The content of Cr(III) was calculated as the difference between the total $\mathrm{Cr}$ content and the $\mathrm{Cr}(\mathrm{VI})$ content.

The other methodology used was physical immobilization of DPC onto C18-poly(styrene-divinylbenzene) bead surfaces. The $\mathrm{Cr}(\mathrm{VI})$, present in natural water 


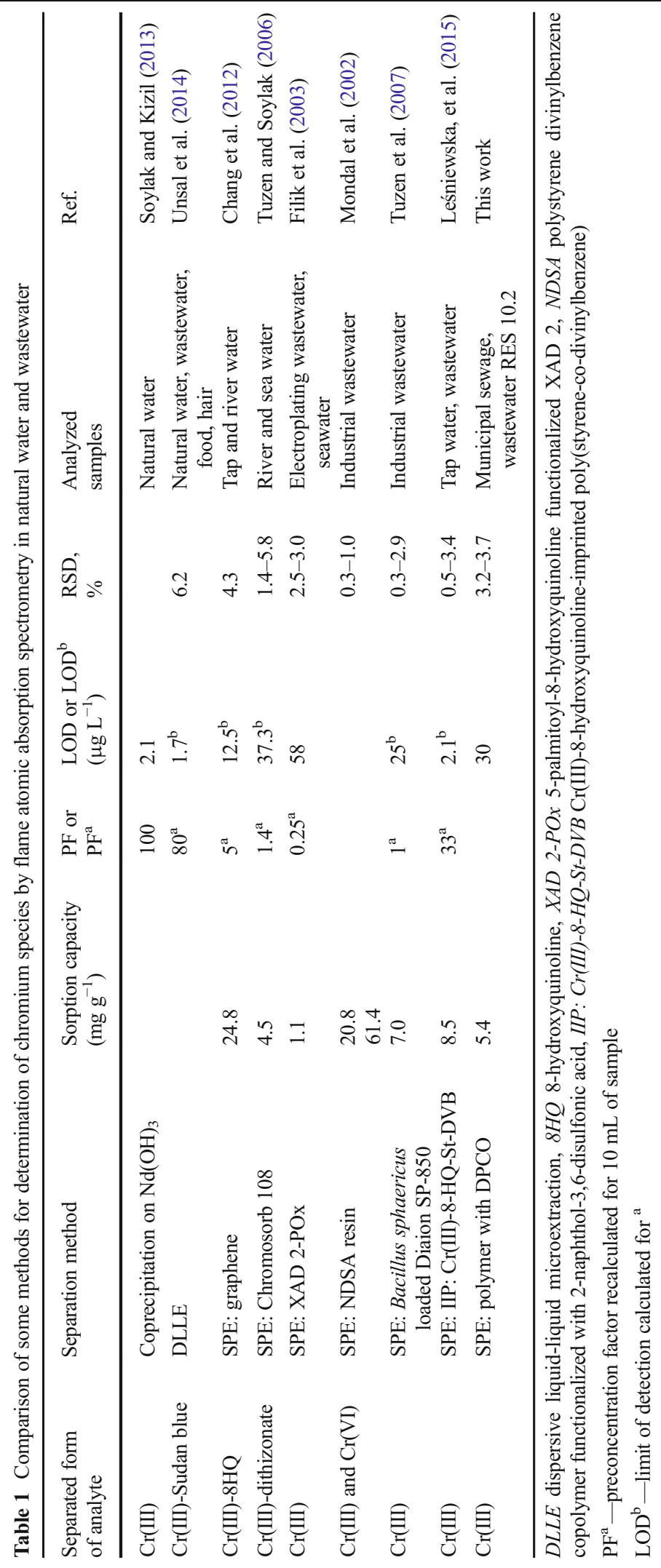


samples, reacted with the immobilized DPC in an acidic environment ( $5 \mathrm{~mol} \mathrm{~L}^{-1} \mathrm{HNO}_{3}$ ) directly on the minicolumn. The retained $\mathrm{Cr}(\mathrm{VI})$ ions were then eluted by a solution of methanol in water and determined by ETAAS. The used beads were discarded from the column by delivering to waste (Long et al. 2005).

Another approach could be an application of sorbents functionalized with DPC or DPCO ligands. Multiwalled carbon nanotubes modified with DPC were used for separation of Cd(II) (Behbahani et al. 2013a), magnetic nanoparticles functionalized with DPC were used for separation of $\mathrm{Hg}$ (II) (Zhai et al. 2010), SBA-15modified nanoporous silica was used for separation of $\mathrm{Cd}(\mathrm{II})$ and $\mathrm{Cu}(\mathrm{II})$ (Bagheri et al. 2012), while magnetic mesoporous silica nanoparticles coated with an ionimprinted polymer containing DPC ligand were used for separation of $\mathrm{Pb}$ (II) (Aboufazeli et al. 2013). Sorbents modified with DPCO ligand, such as silica gel and ion-imprinted polymer, were used for separation and preconcentration of $\mathrm{Hg}(\mathrm{II})$ (Moghimi and Poursharifi 2011) and $\mathrm{Pb}$ (II) (Behbahani et al. 2013b), respectively. So far, such sorbents have not been used for chromium speciation analysis.

The aim of this work was to develop a new method for chromium speciation analysis in contaminated environmental samples, wastewater and municipal sewage, by FAAS. A new polymeric sorbent for selective separation of chromium(III) was designed and prepared. The reagent often used for spectrophotometric determination of $\mathrm{Cr}(\mathrm{VI})$ species, namely DPC, was used for the formation of a $\mathrm{Cr}$ (III)-1,5-diphenylcarbazone (Cr(III)DPCO) complex; next, the complex was incorporated by non-covalent bonds into a methacrylate polymeric structure. The sorption property of obtained sorbent was evaluated under dynamic conditions after removing $\mathrm{Cr}(\mathrm{III})$ ions with EDTA solution. Finally, the polymer was used as a selective sorbent for Cr(III) ions in SPE procedure for chromium speciation analysis.

\section{Experimental}

\subsection{Instrumentation}

For determination of chromium atomic absorption spectrometry with atomization in air-acetylene flame and deuterium, background correction (Solaar M6, Thermo Electron Corporation, UK) was used. The measurements of chromium were performed at wavelength $\lambda=357.9 \mathrm{~nm}$ with a slit of $0.5 \mathrm{~nm}$ by using a chromium hollow cathode lamp (Photron, Australia) operated at 6mA current.

The FT-IR absorption spectrum of polymer (4000$500 \mathrm{~cm}^{-1}$ ) in $\mathrm{KBr}$ was recorded using Thermo Nicolet Magna IR 550 Series II (Nicolet, Japan). Surface area of the polymer was measured by Brunauer, Emmett and Teller (BET) method using surface area and porosity analyzer Gemini VII 2390 (Micrometrics, USA). A scanning electron microscope SEM Inspect S50 (Hitachi, USA) was used for studies of morphology of polymer particles.

A SPE system consisting of laboratory-made glass adsorption column (internal diameter (i.d.) $9 \mathrm{~mm}$ ) filled with $0.1 \mathrm{~g}$ of the polymer, PTFE tubing of i.d. $0.8 \mathrm{~mm}$ and a peristaltic pump Minipuls 3 (Gilson, France) was used.

The $\mathrm{pH}$ values of solutions were controlled with an inoLab pH Level 1 pH meter (WTW, Germany) equipped with an electrode SenTix 21 (WTW, Germany).

\subsection{Reagents and Materials}

Deionized Milli-Q water (Millipore, USA) was used for the preparation of all solutions. Working standard solutions of chromium were prepared daily by appropriate dilution of the stock standard: $\mathrm{Cr}$ (III) $\left(20 \mathrm{~g} \mathrm{~L}^{-1}\right.$, Merck, Germany) or Cr (VI) (1.001 $\mathrm{g} \mathrm{L}^{-1}$, Sigma-Aldrich, Germany). Ammonia solution (25\%) supplied by POCh (Poland) and hydrochloric acid (37\%, TraceSelect, Fluka, Germany) were used for $\mathrm{pH}$ adjustment. EDTA obtained from Merck (Germany) was used as a desorption agent. Nitrates(V) of copper(II), nickel(II), manganese(II) and calcium (Fluka, Germany) were used for studies of competitive ions on chromium separation. 1,5-Diphenylcarbazide (DPC, Puriss, Fluka, Germany), methacrylic acid (MAA, Sigma-Aldrich, Germany), glycol ethylene dimethacrylate (EGDMA, $98 \%$, Sigma-Aldrich, Germany), lauroyl peroxide (Sigma-Aldrich, Germany) and ethanol (96\%, p.a.; POCh, Poland) were used for synthesis of the polymer. De-aeration of polymerization solutions was performed under a high-purity argon atmosphere.

Reference material of wastewater from an urban treatment plant, RES 10.2 (ielab Calidad, Spain), was used for the evaluation of accuracy of the developed procedure. Sewage samples were delivered from a municipal sewage treatment plant (Bialystok, Poland). 


\subsection{Preparation of Polymer and Its Characteristic}

The complex of Cr(III)-1,5-diphenylcarbazone (Cr(III)DPCO) was prepared according to the procedure described in Tunceli and Turker (2002). The prepared complex (containing $6 \mathrm{mg}, 0.12 \mathrm{mmol}$ of $\mathrm{Cr}$ (III)) was dissolved in $11 \mathrm{~mL}$ of ethanol; next, $0.85 \mathrm{~mL}(10 \mathrm{mmol})$ of MAA (functional monomer), $7.5 \mathrm{~mL}$ (40 mmol) of EGDMA (cross-linker) and $0.151 \mathrm{~g}$ lauroyl peroxide (initiator) were added. The polymerization mixture was transferred into glass polymerization ampoules, stirred for $15 \mathrm{~min}$, purged with argon for $10 \mathrm{~min}$, sealed and heated at $60{ }^{\circ} \mathrm{C}$ for $\sim 18 \mathrm{~h}$. The formed polymeric block was crushed in mortar. To remove excess unreacted monomers, polymeric particles were washed with $100 \mathrm{~mL}$ of methylene chloride and dried at $50{ }^{\circ} \mathrm{C}$. The $\mathrm{Cr}$ (III) ions were removed from portions of the polymer with $0.2 \mathrm{~mol} \mathrm{~L}^{-1}$ EDTA. The FT-IR (in $\mathrm{KBr}$ ) spectrum of the polymer was registered, and the following characteristic bonds were observed: $v(-\mathrm{C}=\mathrm{O})$ at $1721 \mathrm{~cm}^{-1}, v(-\mathrm{C}-\mathrm{O})$ at $1252 \mathrm{~cm}^{-1}, v(-\mathrm{C}-\mathrm{N})$ at $1144 \mathrm{~cm}^{-1}, v(-\mathrm{C}=\mathrm{N})$ at $1637 \mathrm{~cm}^{-1}$ and $v(-\mathrm{C}-\mathrm{H})$ bands at $752,1452,2955$ and $2985 \mathrm{~cm}^{-1}$.

Nitrogen sorption analysis was carried out on approximately 0.3 -g portions of polymers degassed for $24 \mathrm{~h}$ at $80^{\circ} \mathrm{C}$. The surface area of the polymer was derived from adsorption isotherms, using a BET method. The BET surface area for the polymer was
$185 \mathrm{~m}^{2} \mathrm{~g}^{-1}$, pore volume was $0.056 \mathrm{~cm}^{3} \mathrm{~g}^{-1}$, and pore diameter was $1.19 \mathrm{~nm}$.

Scanning electron microscopy (SEM) images showed that the particles display an irregular shape and small size $(10-30 \mu \mathrm{m})$. The surface of particles of the polymer is very rough and porous (Fig. 1).

\subsection{Separation Procedure}

The polymeric resin was conditioned by passing $2 \mathrm{~mL}$ of Milli-Q water at a flow rate of $1 \mathrm{~mL} \mathrm{~min}^{-1}$. The $\mathrm{Cr}$ (III) standards and samples were adjusted to $\mathrm{pH} 9$ with ammonia and passed through the column at a flow rate of $0.7 \mathrm{~mL} \mathrm{~min}^{-1}$ for retention of the analyte. Two millilitres of $0.1 \mathrm{~mol} \mathrm{~L}^{-1}$ EDTA at a flow rate of $0.37 \mathrm{~mL} \mathrm{~min}^{-1}$ was used for the elution of $\mathrm{Cr}$ (III) ions. In order to remove $\mathrm{Cr}(\mathrm{VI})$ ions and retain matrix components of real samples, the column was rinsed with $2 \mathrm{~mL}$ of water before the elution step. All results are based on at least three parallel replications.

\section{Results and Discussion}

\subsection{Optimization of the $\mathrm{Cr}(\mathrm{III})$ Separation Procedure}

The suitability of the polymeric sorbent for the separation of $\mathrm{Cr}$ (III) ions was evaluated. The following
Fig. 1 SEM image of surface particles of the polymeric resin functionalized with the DPCO ligand $(\times 15,000$ magnification $)$

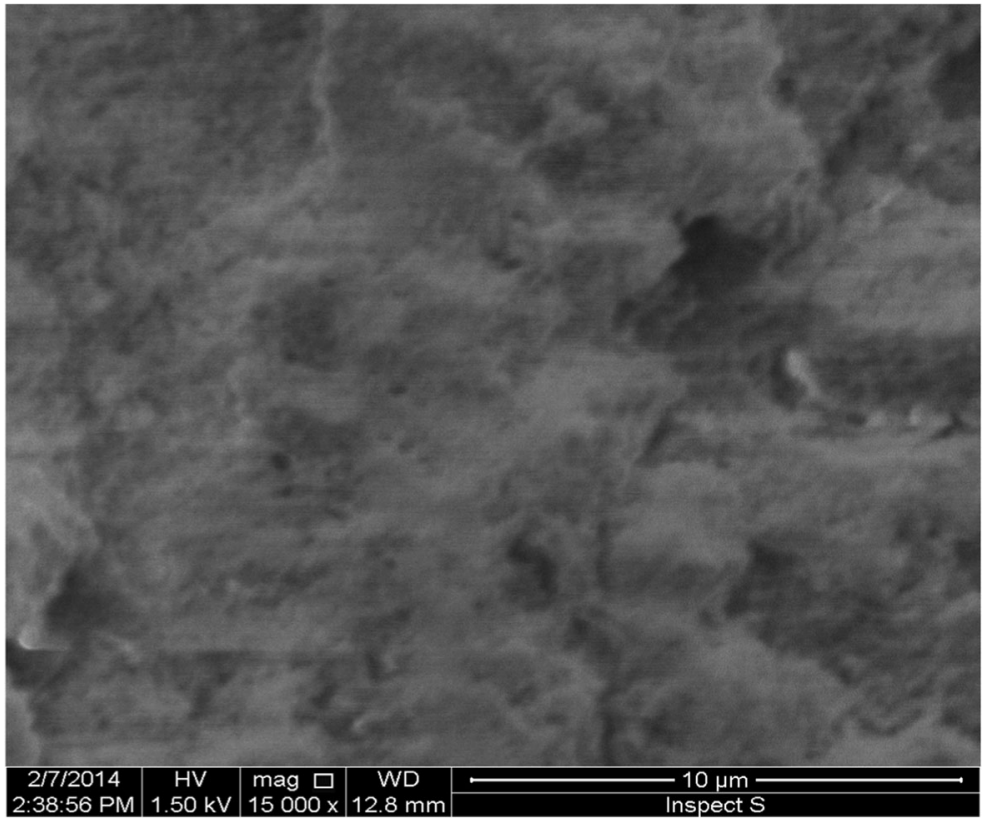


parameters: sample $\mathrm{pH}$, flow rate of sample solution through the column, a kind of eluent, its flow rate and volume were optimized.

The efficiency of retention of both chromium forms on the polymer was studied in the $\mathrm{pH}$ range from 1 to 12. The retention of $\mathrm{Cr}(\mathrm{III})(10 \mu \mathrm{g})$ was in the range 8 $30 \%$ in acidic solutions $(\mathrm{pH} \leq 6)$, rapidly increased to $50 \%$ in solutions of $\mathrm{pH} 7$ and exceeded $90 \%$ in solutions of $\mathrm{pH} \geq 8$ (Fig. 2). The retention of $\mathrm{Cr}(\mathrm{VI})$ $(10 \mu \mathrm{g})$ from samples of $\mathrm{pH} 1-8$ was in the range 30 $50 \%$ and decreased to $20 \%$ at $\mathrm{pH}>9$. This trend is probably due to the effect of unspecific bonding of this form to the functionalized sorbent. The flow rate of

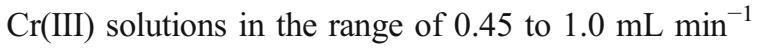
practically did not affect the efficiency of sorption (92$91 \%$ ) and decreased slowly to $83 \%$ at $1.2 \mathrm{~mL} \mathrm{~min}^{-1}$.

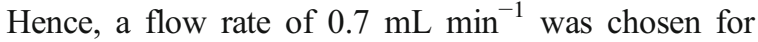
subsequent experiments.

Various stripping agents, mineral and organic acids and complexing agents, were tested for elution of $\mathrm{Cr}$ (III) and $\mathrm{Cr}(\mathrm{VI})$ ions from the sorbent (Fig. 3). The studies showed that the most effective elution of $\mathrm{Cr}$ (III) was obtained with $0.2 \mathrm{~mol} \mathrm{~L}^{-1}$ EDTA, while its elution with $\mathrm{H}_{2} \mathrm{O}$ was negligible. The elution of $\mathrm{Cr}(\mathrm{VI})$ with these two agents was at the level of $60 \%$. In order to improve the selectivity of the procedure, the column was rinsed with water prior to the elution of $\mathrm{Cr}$ (III) ions. This washup step removed most of the $\mathrm{Cr}(\mathrm{VI})$ ions from the column.

The effect of the concentration of EDTA and its flow rate on the recovery of $\mathrm{Cr}$ (III) $(n=3)$ was also studied. The efficiency of $\mathrm{Cr}(\mathrm{III})$ elution raised from $75 \pm 6$ to $101 \pm 1 \%$ with increasing concentration of EDTA from

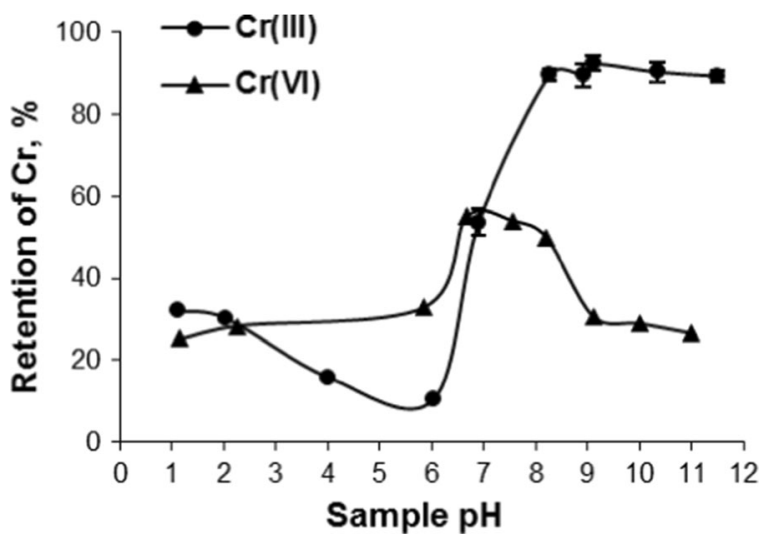

Fig. 2 Effect of sample pH on $\mathrm{Cr}(\mathrm{III})$ and $\mathrm{Cr}(\mathrm{VI})$ retention on the polymeric resin functionalized with DPCO ligand (sample $10 \mu \mathrm{g}$ of $\mathrm{Cr}$, $\mathrm{pH}$ 9, flow rate $0.7 \mathrm{~mL} \mathrm{~min}^{-1}$ )

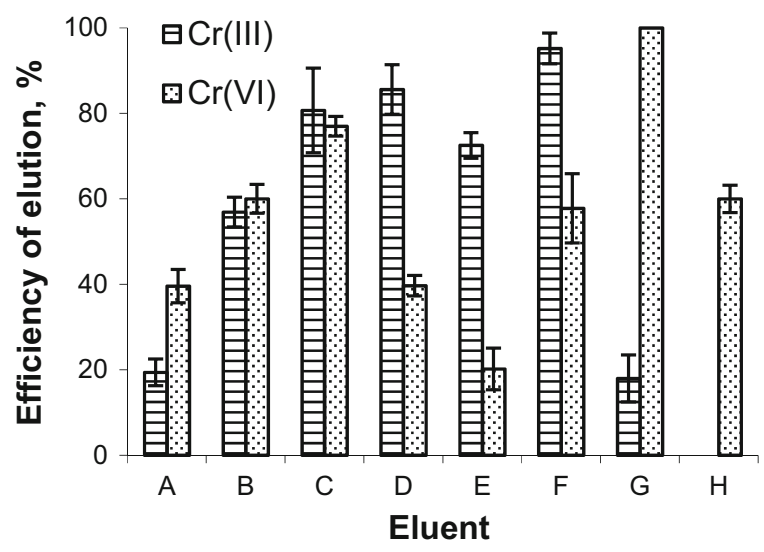

Fig. 3 Efficiency of the elution of $\mathrm{Cr}(\mathrm{III})$ and $\mathrm{Cr}(\mathrm{VI})$ from the polymeric resin functionalized with DPCO ligand with different stripping agents: $A 0.5 \mathrm{~mol} \mathrm{~L}{ }^{-1} \mathrm{HNO}_{3} ; B 2.0 \mathrm{~mol} \mathrm{~L}-1 \mathrm{HNO}_{3} ; C$ $2.0 \mathrm{~mol} \mathrm{~L}^{-1} \mathrm{CH}_{3} \mathrm{COOH} ; D 0.3 \mathrm{~mol} \mathrm{~L}^{-1} \mathrm{HCl}$; $E 0.3 \mathrm{~mol} \mathrm{~L}^{-1}$ thiourea in $0.3 \mathrm{~mol} \mathrm{~L}^{-1} \mathrm{HCl} ; F 0.2 \mathrm{~mol} \mathrm{~L}^{-1}$ EDTA; $G 2.0 \mathrm{~mol} \mathrm{~L}^{-1}$ $\mathrm{NH}_{3}$ aq; $H$ Milli-Q water (volume $2 \mathrm{~mL}$, flow rate $0.37 \mathrm{~mL} \mathrm{~min}^{-1}$ )

0.05 to $0.1 \mathrm{~mol} \mathrm{~L}^{-1}$, while it slightly decreased to $93 \pm$ $6 \%$ for $0.2 \mathrm{~mol} \mathrm{~L}^{-1}$ of EDTA. The effect of the eluent flow rate was tested in the range of $0.37-0.70 \mathrm{~mL} \mathrm{~min}^{-1}$. The recovery of $\mathrm{Cr}(\mathrm{III})(n=3)$ was $100 \pm 0.1 \%$ at a flow

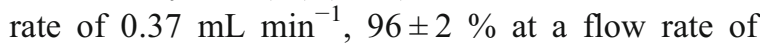
$0.45 \mathrm{~mL} \mathrm{~min}^{-1}, 70 \pm 2 \%$ at a flow rate of $0.55 \mathrm{~mL} \mathrm{~min}^{-1}$ and $59 \pm 2 \%$ at a flow rate of $0.70 \mathrm{~mL} \mathrm{~min}^{-1}$. Then, $0.1 \mathrm{~mol} \mathrm{~L}^{-1}$ EDTA at a flow rate of $0.37 \mathrm{~mL} \mathrm{~min}^{-1}$ was selected as the eluent.

The cumulative recovery of $\mathrm{Cr}$ (III) from the column was evaluated using $0.5-\mathrm{mL}$ portions of $0.1 \mathrm{~mol} \mathrm{~L}^{-1}$ EDTA. The fractions of eluate were successively collected, appropriately diluted and analyzed for analyte content by FAAS. It was found that $2 \mathrm{~mL}$ of the eluent was sufficient for quantitative ( $97 \%$ ) recovery of analyte from the column (Fig. 4).

The breakthrough capacity of the DPCOincorporated polymer was determined in flow mode by passing a standard solution of $\mathrm{Cr}(\mathrm{III})\left(5 \mu \mathrm{g} \mathrm{mL} \mathrm{m}^{-1}\right)$ through the columns $(0.1 \mathrm{~g}$ of polymer). Fractions of effluent $(2 \mathrm{~mL})$ were collected and analyzed for chromium concentration by FAAS. The experiment was completed when the efficiency of chromium retention decreased by $20 \%$. On this basis, the sorption capacity of the polymer for $\mathrm{Cr}(\mathrm{III})$ was calculated as $5.4 \mathrm{mg} \mathrm{g}^{-1}$.

The results were reproducible for 180 successive sorption-desorption cycles performed on the same portion of polymeric sorbent, which confirmed its suitability for flow procedures. In that respect, the prepared 


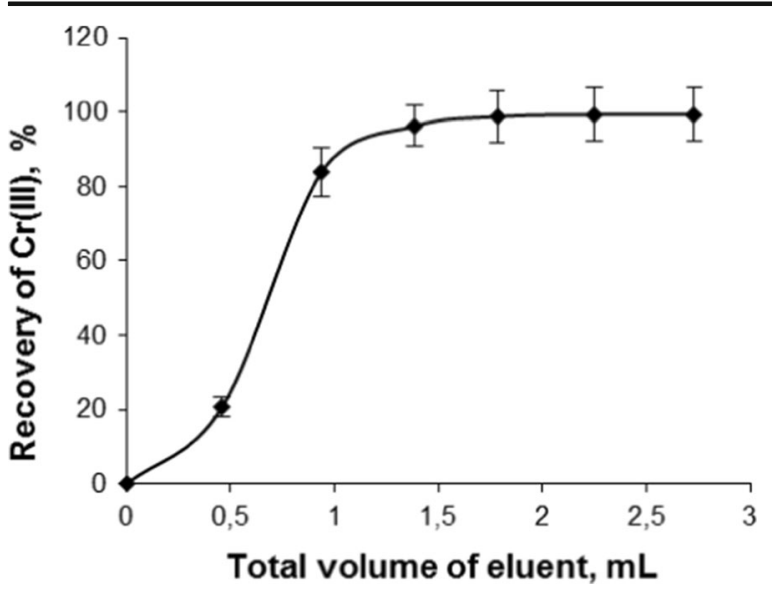

Fig. 4 Total recovery of $\mathrm{Cr}$ (III) from the polymeric resin functionalized with DPCO ligand with $0.1 \mathrm{~mol} \mathrm{~L}^{-1}$ EDTA (flow rate $0.37 \mathrm{~mL} \mathrm{~min}^{-1}$ )

material is superior to other solid sorbents, which retained their adsorption/desorption properties for only five to six analytical cycles (Zhang et al. 2008; Bayramoglu and Arica 2011; Uygun et al. 2013).

\subsection{Effect of Other Ions}

Selectivity of the polymer functionalized with DPCO towards $\mathrm{Cr}(\mathrm{III})$ ions was tested in the presence of other metal ions often present in wastewater ( $\mathrm{Cu}(\mathrm{II}), \mathrm{Ni}(\mathrm{II})$, $\mathrm{Mn}(\mathrm{II}), \mathrm{Ca}(\mathrm{II}))$. The distribution ratios $\left(D, \mathrm{~mL} \mathrm{~g}^{-1}\right)$ and selectivity coefficients $(\alpha)$ of $\mathrm{Cr}(\mathrm{III})$ were calculated from the equations described in Leśniewska, et al. (2011) (Table 2). It was found that the selectivity of the sorbent towards $\mathrm{Cr}$ (III) ions is much better than towards competitive metal ions.

The effect of the presence of $\mathrm{Cu}$ (II) ions on the separation of $\mathrm{Cr}$ (III) ions on the polymer was also studied. Standard solutions of analyte $(10 \mu \mathrm{g})$

Table 2 Selectivity parameters of the polymeric resin functionalized with the DPCO ligand towards Cr(III) ions in the presence of competitive ions (sample $15 \mu \mathrm{g}$ of $\mathrm{Cr}$ (III) $+15 \mu \mathrm{g}$ of other metal ion, $\mathrm{pH} 9$, flow rate $0.7 \mathrm{~mL} \mathrm{~min}^{-1}$ )

\begin{tabular}{llll}
\hline Metal ion, Me & \multicolumn{2}{c}{ Distribution ratio, $D\left(\mathrm{~mL} \mathrm{~g}^{-1}\right)$} & $\begin{array}{l}\text { Selectivity } \\
\text { coefficient, } \alpha\end{array}$ \\
\cline { 2 - 3 } & $\mathrm{Cr}(\mathrm{III})$ & $\mathrm{Me}$ & \\
\hline $\mathrm{Cu}(\mathrm{II})$ & 703 & 140 & 5.0 \\
$\mathrm{Mn}(\mathrm{II})$ & 1194 & 238 & 5.0 \\
$\mathrm{Ni}(\mathrm{II})$ & 647 & 78 & 8.3 \\
$\mathrm{Ca}(\mathrm{II})$ & 707 & 102 & 7.0 \\
\hline
\end{tabular}

containing from 10 to $1000 \mu \mathrm{g}$ of $\mathrm{Cu}(\mathrm{II})$ ions were passed through the column. It was found that even $500 \mu \mathrm{g}$ of $\mathrm{Cu}(\mathrm{II})$ ions did not affect neither retention (92-94 \%) nor recovery (98-113\%) of Cr(III) from the sorbent. A similar effect was observed in the presence of $\mathrm{Mn}(\mathrm{II})$. The recovery of $\mathrm{Cr}(\mathrm{III})$ from the sorbent in the presence of $50 \mu \mathrm{g}$ of $\mathrm{Mn}$ (II) (tenfold excess) was in the range $94-109 \%$. However, during adjustment of sample $\mathrm{pH}$, at solutions containing higher concentrations of $\mathrm{Mn}(\mathrm{II})$ ions, the precipitation of manganese hydroxide, accompanied by co-precipitation of $\mathrm{Cr}(\mathrm{OH})_{3}$, was observed.

The ability of the polymer to separate chromium species at different oxidation states $(\mathrm{Cr}(\mathrm{III})$ and $\mathrm{Cr}(\mathrm{VI}))$ was tested for solutions containing both forms of chromium in the ratios $\mathrm{Cr}(\mathrm{III}) / \mathrm{Cr}(\mathrm{VI})$ as $1: 1$ and 1:5. The solutions were loaded on the column, the next column was rinsed with $2 \mathrm{~mL}$ of Milli-Q water, and $\mathrm{Cr}(\mathrm{III})$ was eluted with $0.1 \mathrm{~mol} \mathrm{~L}^{-1}$ EDTA and determined by FAAS. The results indicate that the prepared sorbent can be used for the separation of $\mathrm{Cr}$ (III) from $\mathrm{Cr}(\mathrm{VI})$ species. The content $\mathrm{Cr}(\mathrm{VI})$ can be calculated as the difference between total content of chromium and Cr(III) form (Table 3).

\subsection{Analytical Performance}

The analytical performance of the method was evaluated under optimized experimental conditions. The efficiency of retention of $5 \mu \mathrm{g} \mathrm{mL} \mathrm{m}^{-1}$ solution of $\mathrm{Cr}$ (III) on the polymer was $95 \pm 1 \%$, while the recovery was $99 \pm 5 \%$. The reproducibility of the developed separation procedure, evaluated for six successive retention and elution cycles and expressed as RSD, was better than $5 \%$. Under the same conditions, the efficiency of retention $\mathrm{Cr}(\mathrm{VI})$ and its elution with Milli-Q water and EDTA solution were tested. It was found that $\mathrm{Cr}(\mathrm{VI})$ ions were retained with an efficiency of $32 \pm 2 \%$. Washing up of sorbent with $2 \mathrm{~mL}$ of Milli-Q water eluted $59 \pm 3 \%$ of $\mathrm{Cr}(\mathrm{VI})$. Low recovery of $\mathrm{Cr}(\mathrm{VI})$ in EDTA fraction $(3 \pm$ $2 \%, n=3$ ) indicated efficient removing of interfering ions prior to $\mathrm{Cr}$ (III) elution.

The calibration graph for the determination of $\mathrm{Cr}$ (III) was constructed by submitting its standard solutions to the separation procedure using $2 \mathrm{~mL}$ of the eluent. The graph was linear up to $15 \mathrm{\mu g} \mathrm{mL}^{-1}$ of $\mathrm{Cr}$ (III) giving the following regression equation: $y=0.0495 \times-0.0195\left(r^{2}=0.9927\right)$. The possibility of separation of $\mathrm{Cr}(\mathrm{III})$ from samples containing a high concentration of analyte was confirmed for 
Table 3 Recovery of Cr(III) from a mixture of Cr(III) and $\mathrm{Cr}(\mathrm{VI})$ ions on the polymeric resin functionalized with DPCO ligand (sample: $\mathrm{pH}$ 9, flow rate $0.7 \mathrm{~mL} \mathrm{~min}^{-1}$; eluent $2 \mathrm{~mL}$ of $0.1 \mathrm{~mol} \mathrm{~L}^{-1} \mathrm{EDTA}$, flow rate $0.37 \mathrm{~mL} \mathrm{~min}^{-1}$; mean value $\pm \mathrm{SD}, n=3$ )

\begin{tabular}{|c|c|c|c|c|c|}
\hline Model sample & $\begin{array}{l}\text { Found mass } \\
\text { of } \mathrm{Cr}(\mathrm{III}) \pm \mathrm{SD} \\
(\mu \mathrm{g})\end{array}$ & $\begin{array}{l}\text { Recovery } \\
\text { of } \mathrm{Cr}(\mathrm{III}) \pm \mathrm{SD} \\
(\%)\end{array}$ & $\begin{array}{l}\text { Determined mass } \\
\text { of } \mathrm{Cr} \pm \mathrm{SD} \\
(\mu \mathrm{g})\end{array}$ & $\begin{array}{l}\text { Calculated mass } \\
\text { of } \mathrm{Cr}(\mathrm{VI}) \\
(\mu \mathrm{g})\end{array}$ & $\begin{array}{l}\text { Recovery } \\
\text { of Cr(VI) } \\
(\%)\end{array}$ \\
\hline $\begin{array}{l}9.8 \mu \mathrm{g} \text { of } \mathrm{Cr}(\mathrm{III})+ \\
9.6 \mu \mathrm{g} \text { of } \mathrm{Cr}(\mathrm{VI})\end{array}$ & $8.4 \pm 0.2$ & $86 \pm 2$ & $19.2 \pm 0.4$ & 10.8 & 113 \\
\hline $\begin{array}{l}4.1 \mu \mathrm{g} \text { of } \mathrm{Cr}(\mathrm{III})+ \\
19.0 \mu \mathrm{g} \text { of } \mathrm{Cr}(\mathrm{VI})\end{array}$ & $3.6 \pm 0.2$ & $87 \pm 2$ & $23.2 \pm 0.5$ & 19.6 & 103 \\
\hline
\end{tabular}

analysis of $100 \mu \mathrm{g}$ of $\mathrm{Cr}$ (III) (recovery of $\mathrm{Cr}$ (III) $=101 \pm$ $5 \%$ ). However, in such case, the eluates should be appropriately diluted prior to measurements by FAAS. The limit of detection (LOD) of the method was calculated as the concentration of analyte equals to threefold standard deviation of the absorbance of blank divided by the slope of the calibration graph $\left(3 \mathrm{SD}_{\text {blank }} / a\right)$, while the limit of quantification (LOQ) was calculated as $10 \mathrm{SD}_{\text {blank }} / a$ (Inczedy et al. 1998). The obtained values were as follows: $\mathrm{LOD}=$ $0.030 \mu \mathrm{g} \mathrm{mL}^{-1}$ and $\mathrm{LOQ}=0.10 \mu \mathrm{g} \mathrm{mL}^{-1}$.

The accuracy of the method was confirmed by analysis of the reference material of municipal wastewater RES 10.2 with the certified value of the total concentration of chromium $\left(4.55 \mu \mathrm{g} \mathrm{mL}^{-1}\right)$. As was demonstrated earlier (Leśniewska et al. 2015), chromium is present in RES 10.2 only in the Cr(III) form. It was found that the concentration of $\mathrm{Cr}$ (III) in the reference material determined after the separation procedure was in good agreement with the certified value for total chromium (Table 4). In terms of sensitivity, the method is

Table 4 Recovery of Cr(III) from real samples on the polymeric resin functionalized with DPCO ligand (sample: $\mathrm{pH} 9$, flow rate $0.7 \mathrm{~mL} \mathrm{~min}{ }^{-1}$; eluent $2 \mathrm{~mL}$ of $0.1 \mathrm{~mol} \mathrm{~L}^{-1}$ EDTA, flow rate $0.37 \mathrm{~mL} \mathrm{~min}^{-1}$; mean value $\pm \mathrm{SD}, n=3$ )

\begin{tabular}{lll}
\hline Sample & $\begin{array}{l}\text { Found mass of } \\
\text { Cr(III) } \pm \text { SD }(\mu \mathrm{g})\end{array}$ & $\begin{array}{l}\text { Recovery } \\
\text { of Cr(III) } \\
\pm \mathrm{SD}(\%)\end{array}$ \\
\hline Sewage $^{\mathrm{a}}+14 \mu \mathrm{g}$ of Cr(III) & $15.3 \pm 0.5$ & $109 \pm 4$ \\
Treated sewage $^{\mathrm{a}}+14 \mu \mathrm{g}$ of & $13.2 \pm 0.4$ & $94 \pm 3$ \\
Cr(III) & $\begin{array}{c}4.21 \pm \\
\text { Wastewater RES 10.2 }\end{array}$ & $93 \pm 4$ \\
& $0.16 \mu \mathrm{mL}^{-1 \mathrm{c}}$ & \\
\hline
\end{tabular}

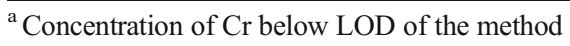

${ }^{\mathrm{b}}$ Wastewater RES 10.2 - property value of Cr $4.55 \pm 0.055 \mu \mathrm{g} \mathrm{mL}^{-1}$

${ }^{\mathrm{c}}$ In concentration units comparable to other published methods (Tunceli and Turker 2002; Narin et al. 2006; Rajesh et al. 2008), but it is faster (seven samples/h) and non-laborious.

\subsection{Method Application}

The method was applied to the determination of $\mathrm{Cr}$ (III) in raw and treated municipal sewage. Samples were filtered through a $0.45-\mu \mathrm{m}$ Supelco membrane filter, adjusted to $\mathrm{pH} 9$ with ammonia solution and left for equilibration. Because the concentration of $\mathrm{Cr}$ (III) in analyzed samples was below LOQ of the method, the procedure was applied to samples spiked with $14 \mu \mathrm{g}$ of $\mathrm{Cr}(\mathrm{III})$. The recovery of $\mathrm{Cr}(\mathrm{III})$ was in the range of 93$109 \%$ (Table 4), which indicates a significant interference by other metal ions commonly present in such samples. The reproducibility of the separation procedure for different samples was below $3.5 \%$. This confirmed that the developed SPE method using a resin functionalized with DPCO is suitable for chromium speciation analysis in contaminated samples.

It is worth mentioning that the concentration of chromium in treated sewage samples collected from a municipal sewage treatment plant (Bialystok, Poland) determined by ETAAS was equal to $0.045 \mu \mathrm{g} \mathrm{mL}{ }^{-1}$, which is below the limit established in Poland by the Ordinance of the Minister of Environment (2014).

\section{Conclusions}

A dynamic SPE procedure for the study of speciation of chromium in wastewater and sewage was developed. A new solid material containing the DPCO included in a methacrylate polymeric matrix was designed and prepared for the separation of $\mathrm{Cr}$ (III) species. The new 
sorbent is characterized by high selectivity towards $\mathrm{Cr}(\mathrm{III})$ ions, good stability and high sorption capacity (see Table 1). The proposed method was characterized by good reproducibility and low detection limit, comparable to previously published methods (Table 1). Successful validation of the method was performed with the reference material of municipal wastewater RES 10.2. The utility of the method was confirmed in the analysis of complex samples as municipal sewage, while only a few methods presented in the literature have been used for analysis of such samples.

Considering the environmental aspect of our study, it was concluded that the developed method may become a novel analytical tool useful in environmental speciation analysis. The concentration of $\mathrm{Cr}(\mathrm{VI})$ can be calculated as the difference between the total concentration of chromium and the $\mathrm{Cr}$ (III) form.

Acknowledgments The authors kindly acknowledge the financial support from the Polish National Science Centre (DEC-2012/07/B/ ST4/01581). We thank A.Z. Wilczewska, Ph.D. (University of Bialystok, Institute of Chemistry) for assistance in the preparation of the polymer functionalized with DPCO. The surface area and porosity analyzer and scanning electron microscope were funded by the EU as part of the Operational Programme Development of Eastern Poland 2007-2013, project: POPW.01.03.00-20-034/09-00.

Open Access This article is distributed under the terms of the Creative Commons Attribution 4.0 International License (http:// creativecommons.org/licenses/by/4.0/), which permits unrestricted use, distribution, and reproduction in any medium, provided you give appropriate credit to the original author(s) and the source, provide a link to the Creative Commons license, and indicate if changes were made.

\section{References}

Aboufazeli, F., Lotfi, Z. Z., Hamid, R., Sadeghi, O., Karimi, M., \& Najafi, E. (2013). Novel ion imprinted polymer magnetic mesoporous silica nano-particles for selective separation and determination of lead ions in food samples. Food Chemistry, 141, 3459-3465.

Bagheri, A., Behbahani, M., Amini, M. M., Sadeghi, O., Taghizade, M., Baghayi, L., \& Salarian, M. (2012). Simultaneous separation and determination of trace amounts of $\mathrm{Cd}(\mathrm{II})$ and $\mathrm{Cu}$ (II) in environmental samples using novel diphenylcarbazide modified nanoporous silica. Talanta, 89, 455-461.

Barałkiewicz, D., Pikosz, B., Belter, M., \& Marcinkowska, M. (2013). Speciation analysis of chromium in drinking water samples by ion-pair reversed-phase HPLC-ICP-MS: validation of the analytical method and evaluation of the uncertainty budget. Accreditation and Quality Assurance, 18, 391-401.

Bayramoglu, G., \& Arica, M. Y. (2011). Synthesis of Cr(VI)imprinted poly(4-vinyl pyridine-co-hydroxyethyl methacrylate) particles: its adsorption propensity to $\mathrm{Cr}(\mathrm{VI})$. Journal of Hazardous Materials, 187, 213-221.

Behbahani, M., Bagheri, A., Amini, M. M., Sadeghi, O., Salarian, M., Najafi, F., \& Taghizadeh, M. (2013a). Application of multiwalled carbon nanotubes modified by diphenylcarbazide for selective solid phase extraction of ultra traces $\mathrm{Cd}(\mathrm{II})$ in water samples and food products. Food Chemistry, 141, 48-53.

Behbahani, M., Bagheri, A., Taghizadeh, M., Salarian, M., Sadeghi, O., Adlnasab, L., \& Jalali, K. (2013b). Synthesis and characterisation of nano structure lead (II) ion-imprinted polymer as a new sorbent for selective extraction and preconcentration of ultra trace amounts of lead ions from vegetables, rice, and fish samples. Food Chemistry, 138, 2050-2056.

Report on Carcinogens, Thirteenth Edition. (2014). Chromium hexavalent compounds, CAS No. 18540-29-9, National Toxicology Program, Department of Health and Human Services. (http://ntp.niehs.nih.gov/go/roc13).

Chang, Q., Song, S., Wang, Y., Li, J., \& Ma, J. (2012). Application of grapheme as a sorbent for preconcentration and determination of trace amounts of chromium(III) in water samples by flame atomic absorption spectrometry. Analytical Methods, 4, 1110-1016.

EEA Technical report. (2015). European Union emission inventory report 1990-2013 under the UNECE Convention on Longrange Transboundary Air Pollution (LRTAP) (Vol. 8, p. 69). Luxembourg: Publications Office of the European Union. http://www.eea.europa.eu/publications/lrtap-emissioninventory-report/\#parent-fieldname-title; 18.12.2015.

EPA (2014). Priority pollutant list: http://www2.epa.gov/eg/toxicand-priority-pollutants-under-clean-water-act (6.12.2015)

Filik, H., Doğutan, M., \& Apak, R. (2003). Speciation analysis of chromium by separation on a 5-palmitoyl oxine-functionalized XAD-2 resin and spectrophotometric determination with diphenylcarbazide. Analytical and Bioanalytical Chemistry, 376, 928-933.

Hoet, P. (2005). Speciation of chromium in occupational exposure and clinical aspects. In R. Cornelis, H. Crews, J. Caruso, \& K. G. Heumann (Eds.), Handbook of elemental speciation II: species in the environment, food, medicine \& occupational health (pp. 135-157). Chichester: Wiley, Ltd.

IARC. (1990). Monographs on the evaluation of carcinogenic risks to humans. Chromium, nickel and welding (Vol. 49, pp. 49-214). Lyon: WHO International Agency for Research on Cancer.

Inczedy, J, Lengyel, T, Ure, AM, Gelencser, A, Hulanicki, A (1998) Compendium of analytical nomenclature. 3rd ed. IUPAC, Blackwell Science.

Kotaś, J., \& Stasicka, Z. (2000). Chromium occurrence in the environment and methods of its speciation. Environmental Pollution, 107, 263-283.

Leśniewska, B., Kosińska, M., Godlewska-Żyłkiewicz, B., Zambrzycka, E., \& Wilczewska, A. Z. (2011). Studies of new sorbents based on imprinted complexes of Pt(II) with thiosemicarbazone derivatives for separation and determination of platinum in environmental samples by electrothermal atomic absorption spectrometry. Mikrochimica Acta, 175, 273-282.

Leśniewska, B., Godlewska-Żyłkiewicz, B., \& Wilczewska, A. Z. (2012). Separation and preconcentration of trace amounts of 
$\mathrm{Cr}(\mathrm{III})$ ions on ion imprinted polymer from water samples. Microchemical Journal, 105, 88-93.

Leśniewska, B., Trzonkowska, L., Zambrzycka, E., \& GodlewskaŻyłkiewicz, B. (2015). Multi-commutation flow system with on-line solid phase extraction exploiting the ion-imprinted polymer and FAAS detection for chromium speciation analysis in sewage samples. Analytical Methods, 7, 1517-1526.

Long, X., Miro, M., \& Hansen, H. (2005). Universal approach for selective trace metal determinations via sequential injection-bead injection-lab on valve using renewable hydrophobic bead surfaces as reagent carriers. Analytical Chemistry, 77, 6032-6041.

Ma, J., Yuan, D., \& Byrne, R. H. (2014). Flow injection analysis of trace chromium(VI) in drinking water with a liquid waveguide capillary cell and spectrophotometric detection. Environmental Monitoring and Assessment, 186, 367-373.

Madzgalj, A., Baesso, M. L., \& Franko, M. (2008). Flow injection thermal lens spectrometric detection of hexavalent chromium. European Physical Journal Special Topics, 153, 503-506.

Metze, D., Jakubowski, N., \& Klockow, D. (2005). Speciation of chromium in environment and food. In R. Cornelis, H. Crews, J. Caruso, \& K. G. Heumann (Eds.), Handbook of elemental speciation II: species in the environment, food, medicine \& occupational health (pp. 120-134). Chichester: Wiley, Ltd.

Moghimi, A., \& Poursharifi, M. J. (2011). Preconcentration and determination of mercury(II) using modified silica gel with diphenylthiocarbazone by cold vapour atomic absorption spectrometry. Asian Journal of Chemistry, 23, 4117.

Mondal, B. C., Das, D., \& Das, A. K. (2002). Synthesis and characterization of a new resin functionalized with 2-naphthol-3,6-disulfonic acid and its application for the speciation of chromium in natural water. Talanta, 56, 145-152.

Mulaudzi, L. V., Staden, J. F., \& Stefan, R. I. (2002). Determination of chromium(III) and chromium(VI) by use of a spectrophotometric sequential injection system. Analytica Chimica Acta, 467, 51-60.

Namieśnik, J., \& Rabajczyk, A. (2012). Speciation analysis of chromium in environmental samples. Critical Reviews in Environmental Science and Technology, 42, 327-377.

Narin, I., Soylak, M., Kayakirilmaz, K., Elci, L., \& Dogan, M. (2002). Speciation of $\mathrm{Cr}(\mathrm{III})$ and $\mathrm{Cr}(\mathrm{VI})$ in tannery wastewater and sediment samples on Ambersorb 563 resin. Analytical Letters, 35, 1437-1452.

Narin, I., Surme, Y., Soylak, M., \& Dogand, M. (2006). Speciation of $\mathrm{Cr}(\mathrm{III})$ and $\mathrm{Cr}(\mathrm{VI})$ in environmental samples by solid phase extraction on Ambersorb 563 resin. Journal of Hazardous Materials, B136, 579-584.

Narin, I., Kars, A., \& Soylak, M. (2008). A novel solid phase extraction procedure on Amberlite XAD-1180 for speciation of $\mathrm{Cr}(\mathrm{III}), \mathrm{Cr}(\mathrm{VI})$ and total chromium in environmental and pharmaceutical samples. Journal of Hazardous Materials, $150,453-458$

Ordinance of the Minister of Environment concerning the conditions for spreading sewage into the water or soil, and on substances particularly harmful to the aquatic environment. Official Journal (2014),1800, p. 1-42 (in Polish).

Pena, F., Lavilla, I., \& Bendicho, C. (2008). Immersed single-drop microextraction interfaced with sequential injection analysis for determination of $\mathrm{Cr}(\mathrm{VI})$ in natural waters by electrothermal atomic absorption spectrometry. Spectrochimica Acta B, 63, 498-503.
Pettine, M., \& Capri, S. (2005). Removal of humic matter interference in the determination of $\mathrm{Cr}(\mathrm{VI})$ in soil extracts by the diphenylcarbazide method. Analytica Chimica Acta, 540, 239-246.

Pyrzyńska, K. (2012). Non-chromatographic speciation analysis of chromium in natural waters. International Journal of Environmental Analytical Chemistry, 92, 1262-1275.

Rajesh, N., Jalan, R. K., \& Howany, P. (2008). Solid phase extraction of chromium (VI) from aqueous solutions by adsorption of its diphenylocarbazide complex on an Amberlite XAD-4 resin column. Journal of Hazardous Materials, 150, 723-727.

Ščančar, J., \& Milačič, R. (2014). A critical overview of $\mathrm{Cr}$ speciation analysis based on high performance liquid chromatography and spectrometric techniques. Journal of Analytical Atomic Spectrometry, 29, 427-443.

Soylak, M., \& Kizil, N. (2013). Neodymium(III) hydroxide coprecipitation-FAAS system for the speciation of chromium in natural waters. Atom Spectrosc, 34, 216-220.

Stanisławska, M., Janasik, B., \& Wasowicz, W. (2013). Application of high performance liquid chromatography with inductively coupled plasma mass spectrometry (HPLC-ICPMS) for determination of chromium compounds in the air at the workplace. Talanta, 117, 14-19.

Themelis, D. G., Kika, F. S., \& Economou, A. (2006). Flow injection direct spectrophotometric assay for the speciation of trace chromium(III) and chromium(VI) using chromotropic acid as chromogenic reagent. Talanta, 69, 615-620.

Tunceli, A., \& Turker, A. (2002). Speciation of Cr(III) and Cr(VI) in water after preconcentration of its 1,5-diphenylcarbazone complex on amberlite XAD-16 resin and determination by FAAS. Talanta, 57, 1199-1204.

Tuzen, M., \& Soylak, M. (2006). Chromium speciation in environmental samples by solid phase extraction on Chromosorb 108. Journal of Hazardous Materials, 129, 266-273.

Tuzen, M., Uluozlu, O. D., \& Soylak, M. (2007). Cr(VI) and $\mathrm{Cr}$ (III) speciation on Bacillus sphaericus loaded diaion SP850 resin. Journal of Hazardous Materials, 144, 549-555.

Unsal, Y. E., Tuzen, M., \& Soylak, M. (2014). Speciation of chromium by the combination of dispersive liquid-liquid microextraction and microsample injection flame atomic absorption spectrometry. Turkish Journal of Chemistry, 38, 173-181.

Uygun, M., Feyzioğlu, E., Özçalıșkan, E., Caka, M., Ergen, A., Akgöl, A., \& Denizli, A. (2013). New generation ionimprinted nanocarrier for removal of $\mathrm{Cr}(\mathrm{VI})$ from wastewater. Journal of Nanoparticle Research, 15, 1-11.

Yuan, D., Fu, D., Wang, R., \& Yuan, J. (2008). Rapid determination of chromium(VI) in electroplating waste water by use of a spectrophotometric flow injection system. Spectrochimica Acta B, 71, 276-279.

Zhai, Y., Duan, S., He, Q., Yang, X., \& Han, Q. (2010). Solid phase extraction and preconcentration of trace mercury(II) from aqueous solution using magnetic nanoparticles doped with 1,5diphenylcarbazide. Mikrochimica Acta, 169, 353-360.

Zhang, N., Suleiman, J. S., He, M., \& Hu, B. (2008). Chromium(III)-imprinted silica gel for speciation analysis of chromium in environmental water samples with ICP-MS detection. Talanta, 75, 536-543.

Zhao, X., Song, N., Zhou, W., \& Jia, Q. (2012). Preconcentration procedures for determination of chromium using atomic spectrometric techniques. Central European Journal of Chemistry, 10, 927-937. 